\title{
Coralligenous habitat: patterns of vertical distribution of macroalgal assemblages
}

\author{
LUIGI PIAZZI ${ }^{1}$ and DAVID BALATA ${ }^{2}$ \\ ${ }^{1}$ Centro Interuniversitario di Biologia Marina ed Ecologia Applicata, v.le N. Sauro 4, Livorno, Italy. \\ 2 School of Biological and Environmental Sciences, Science Building West, University College Dublin. Belfield, Dublin 4 , \\ Ireland. E-mail: david.balata@gmail.com
}

\begin{abstract}
SUMMARY: The present study investigates patterns of distribution of macroalgal coralligenous assemblages in relation to depth and evaluates the role of different environmental conditions on these patterns. Two depths ( 30 and $40 \mathrm{~m}$ ) were investigated off small islands and off continental coasts in order to select two different environmental conditions. Results showed differences between depths in the structure of assemblages around islands, while along the continental coasts these patterns were not evident. Moreover, differences between assemblages related to different environmental conditions were more evident in the shallower zone of distribution of the coralligenous habitat. This correlative study did not allow us to identify any cause-effect relationship, but patterns we detected agree with those of other studies, suggesting that alterations in the environmental conditions may be the cause of the decrease in differences among assemblages developing at different depths and may lead to a higher spatial homogenization and an impoverishment of the whole subtidal system.
\end{abstract}

Keyworks: coralligenous habitat, depth, disturbance, macroalgae, Mediterranean Sea.

RESUMEN: HÁBITAT CORALÍGENO: PATRONES DE DISTRIBUCIÓN VERTICAL DE CONJUNTOS DE MACROALGAS. - Este estudio investiga los patrones de distribución de las comunidades algales del hábitat coralígeno en relación a la profundidad y evalúa el papel de las diferentes condiciones ambientales en la formación de estos patrones. Se han muestreado dos profundidades $(30$ y $40 \mathrm{~m}$ ) en pequeñas islas y en la costa continental. Los resultados muestran diferencias entre profundidades en la estructura de las comunidades entre islas, mientras que estas diferencias no son evidentes en el continente. Además las diferencias encontradas son más evidentes a 30 metros. Este estudio correlacional no nos permite establecer ninguna relación causa-efecto; sin embargo, los patrones detectados están de acuerdo con lo observado en otros trabajos, lo que sugiere que las alteraciones en las condiciones ambientales pueden ser la causa de la disminución de las diferencias entre comunidades que se desarrollan a profundidades distintas y pueden provocar una mayor homogeneidad espacial y un empobrecimiento de la zona sublitoral.

Palabras clave: hábitat coralígeno, profundidad, perturbación, macroalgas, mar Mediterráneo.

\section{INTRODUCTION}

Depth is one of the main causes of distribution in marine organisms (Vadas and Steneck, 1988; Garrabou et al., 2002; Konar et al., 2009; Terlizzi et al., 2010). In fact, the main physical factors regulating life in marine systems, such as light, water movement, temperature, sedimentation and nutrient availability are depth-related (Pérès and Picard, 1964). In coastal habitats, other factors, such as the morphology of the bottom, physical and chemical characteristics of water and biotic interactions, can modi- fy the vertical patterns of distribution (Underwood, 1992; Benedetti-Cecchi et al., 2000; Glasby and Connel, 2001; Irving and Connel, 2002; Airoldi, 2003; Diez et al., 2003; Dauer et al., 2008). In this context, human activities can influence patterns of variability, amplifying these changes (Chapman et al., 1995). This latter aspect is understudied, although it might furnish fundamental ecological information for understanding the spatial patterns in impact evaluations or monitoring surveys.

In the Mediterranean Sea, shallow subtidal rocky habitats are dominated by photophilous assemblages of 

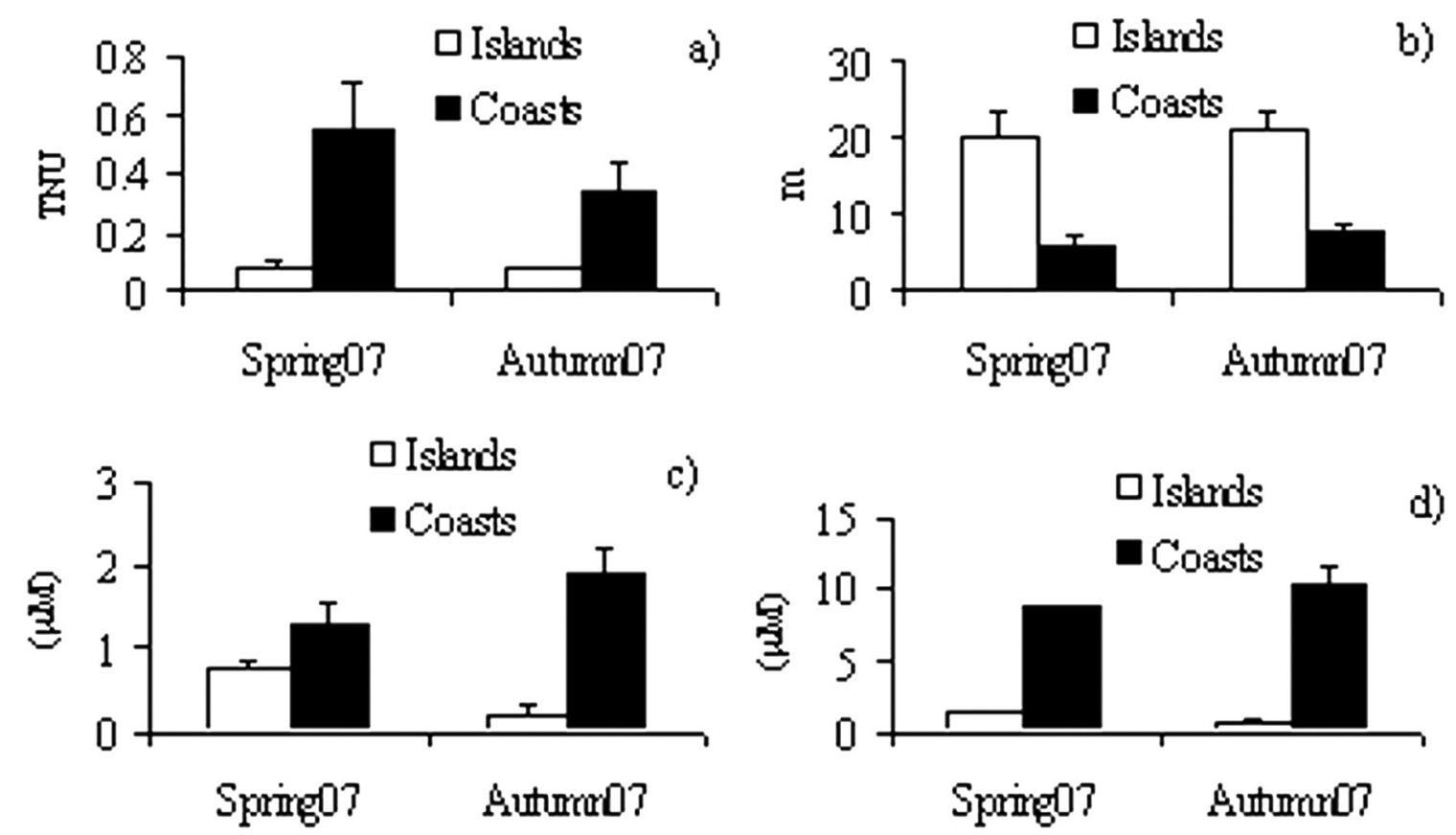

FIG. 1. - Values of turbidity (measured through a multiparametric probe) (a), transparency (measured through Secchi disc) (b), concentration of $\mathrm{NH}_{4}$ (c) and $\mathrm{NO}_{3}(\mathrm{~d})$ obtained in two different surveys along the Tuscany coasts (mean $\pm \mathrm{SE}, \mathrm{n}=8$ )

macroalgae mostly belonging to Ochrophyta (Gili and Ros, 1985; Balata and Piazzi, 2008), while the deep subtidal zone is characterized by peculiar assemblages associated with coralligenous habitats (sensu Ballesteros, 2006). This habitat consists of calcareous structures built by algae belonging to the family Corallinales and developing under reduced irradiance. Vertical distribution of coralligenous assemblages has not been suitably assessed, though several patterns have emerged from previous studies (Balata et al., 2006). Moreover, although the effects of different kinds of disturbance on coralligenous assemblages have been investigated (Balata et al., 2007a, 2007b; Piazzi et al., 2007), there is no evidence of the influence of environmental conditions on vertical patterns.

The present study aimed to describe patterns of distribution of macroalgal coralligenous assemblages in relation to depth and to determine whether these patterns remain constant under different environmental conditions. The following hypotheses were tested: i) the structure of coralligenous assemblages differs between depths, and 2) patterns of vertical distribution change under different environmental conditions related to coast vs island habitats.

\section{MATERIALS AND METHODS}

The study was carried out in Tuscany, in the NW Mediterranean Sea, in summer 2008. Two depths (30 and $40 \mathrm{~m}$ ) were investigated on horizontal rocky bottoms; we chose these depths because they can be considered, respectively, as the minimal and the maximal depth at which it is possible to find coralligenous habitats on rocky substrate in the study area. In order to select two different environmental conditions, small islands and continental coasts were considered. In fact, small islands and continental coasts can generally differ in environmental conditions and levels of anthropogenic disturbance (Benedetti-Cecchi et al., 2003). In our study this model was based on data previously obtained by the monitoring survey carried out by ARPAT (Environmental Agency of Tuscany) along the Tuscan coasts (Fig. 1). For each condition and depth, 4 sites $\left(20 \mathrm{~m}^{2}\right)$ several kilometres from each other were chosen (Fig. 2) and three replicate plots of $400 \mathrm{~cm}^{2}$ were sampled at each site (Boudouresque 1971, 1973). All organisms were collected in each plot by scraping the substrate with a hammer and a chisel. Macroalgae were identified and the abundance of each species was expressed as percentage cover. Total percentage cover was calculated by summing the percentage cover of each species found in each plot. Taxonomic nomenclature follows Guiry and Nic Dhonncha (2009).

Data were analyzed by permutational multivariate analysis of variance (PERMANOVA, Anderson, 2001) with a 3-way model with Depth (30 m vs. $40 \mathrm{~m})$ and Condition (Island vs. Coast) as fixed and crossed factors, and Site (4 levels) as a random factor nested in the interaction Depth $\times$ Condition. Bray-Curtis measures of dissimilarities in untransformed data were used to calculate a matrix of distances between pairs of samples. A pairwise test was used to discriminate among levels of significant factors. A SIMPER test (Clarke 1993) was used to determine species responsible for multivariate patterns. SIMPER tests analysed the comparisons between the levels of the Condition $\times$ Depth 


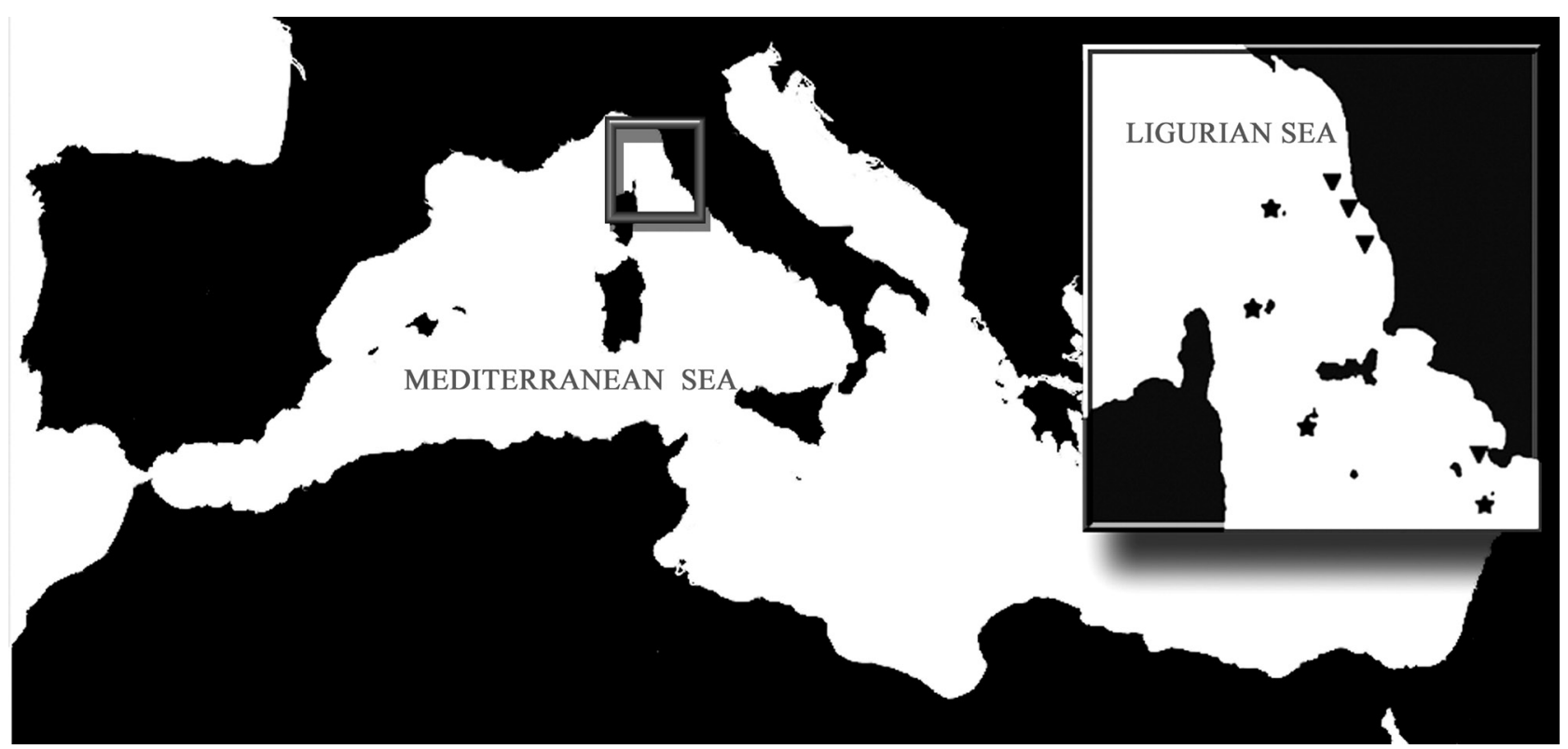

FIG. 2. - Map of the study area. Symbols indicate the sampling sites. Stars, small islands; triangles, continental coasts

TABLE 1. - Results of PERMANOVA analysis. Significant results are in bold.

\begin{tabular}{|c|c|c|c|c|c|}
\hline Source & df & MS & Pseudo-F & \multicolumn{2}{|c|}{$\begin{array}{c}\mathrm{P}(\text { perm }) \begin{array}{c}\text { Number } \\
\text { of } \\
\text { permutations }\end{array}\end{array}$} \\
\hline Condition (C) & 1 & 11157 & 4.6331 & 0.002 & 999 \\
\hline Depth (D) & 1 & 16254 & 6.7495 & 0.001 & 999 \\
\hline $\mathrm{C} \times \mathrm{D}$ & 1 & 6855 & 2.8466 & 0.024 & 999 \\
\hline Site $(C \times D)$ & 12 & 2408.2 & 4.3798 & 0.001 & 999 \\
\hline Residual & 32 & 549.84 & & & \\
\hline Total & 47 & & & & \\
\hline \multirow{4}{*}{\multicolumn{2}{|c|}{ Pairwise tests $(\mathrm{C} \times \mathrm{D})$}} & $-30 \mathrm{~m}:$ & coast, island & 0.002 & \\
\hline & & $-40 \mathrm{~m}:$ & coast, island & 0.205 & \\
\hline & & coast & $-30 m,-40 m$ & 0.181 & \\
\hline & & island & $-30 \mathrm{~m},-40 \mathrm{~m}$ & 0.001 & \\
\hline
\end{tabular}

interaction that were significant in the pairwise tests (PERMANOVA).

A 2-dimensional nMDS (non-metric multidimensional scaling) based on centroids for replicate sites was used as a graphical representation of the data. Distances among centroids were obtained using principal coordinate axes from the original Bray-Curtis matrix.

Values of species richness and total percentage cover were analyzed by a 3-way ANOVA, utilizing the same factors and levels as those described for the multivariate analysis. Homogeneity of variances was checked using the Cochran $C$-test. The StudentNewman-Keuls (SNK) test was used for a posteriori multiple comparison of means (Underwood, 1997).

\section{RESULTS}

An encrusting calcareous layer completely covered the substrate in all samples and it was mostly constituted by the Corallinales Mesophyllum alternans (Foslie) Cabioch and Mendoza; Mesophyllum macroblastum
TABLE 2. - Results of SIMPER test

\begin{tabular}{|c|c|c|c|}
\hline Taxa & $\begin{array}{l}\text { Average } \\
\text { abundance }\end{array}$ & $\begin{array}{l}\text { Average } \\
\text { abundance }\end{array}$ & $\begin{array}{c}\text { Contribution } \\
\%\end{array}$ \\
\hline Island & $-30 \mathrm{~m}$ & $-40 m$ & \\
\hline Flabellia petiolata & 34.9 & 4.4 & 18.6 \\
\hline Peyssonnelia rubra & 20.2 & 47.9 & 17.2 \\
\hline Halimeda tuna & 27.7 & 1.1 & 16.6 \\
\hline Womersleyella setacea & 22.5 & 6.2 & 11.7 \\
\hline Peyssonnelia squamaria & 3.6 & 10.0 & 5.8 \\
\hline Meredithia microphylla & 0.5 & 8.7 & 4.9 \\
\hline Osmundea pelagosae & 4.2 & 7.4 & 4.3 \\
\hline Zanardina typus & 1.4 & 4.4 & 3.4 \\
\hline Eupogodon planus & 0.3 & 2.5 & 1.4 \\
\hline Valonia macrophysa & 1.6 & 0.8 & 1.2 \\
\hline Acrodiscus vidovichii & 0.5 & 1.6 & 1.0 \\
\hline Dictyota linearis & 1.5 & 0.0 & 0.9 \\
\hline$-30 m$ & coast & island & \\
\hline Flabellia petiolata & 5.1 & 34.9 & 20.8 \\
\hline Halimeda tuna & 1.9 & 27.7 & 18.6 \\
\hline Peyssonnelia rubra & 34.6 & 20.2 & 13.2 \\
\hline Womersleyella setacea & 7.9 & 22.5 & 12.6 \\
\hline Zanardina typus & 10.0 & 1.4 & 7.0 \\
\hline Tricleocarpa fragilis & 5.2 & 0.0 & 3.7 \\
\hline Osmundea pelagosae & 3.5 & 4.2 & 2.9 \\
\hline Peyssonnelia squamaria & 1.1 & 3.6 & 2.7 \\
\hline Acrodiscus vidovichii & 1.6 & 0.5 & 2.03 \\
\hline Valonia macrophysa & 0.1 & 1.6 & 1.1 \\
\hline Dictyota linearis & 0.7 & 1.5 & 0.9 \\
\hline Meredithia microphylla & 1.3 & 0.5 & 0.9 \\
\hline
\end{tabular}

(Foslie) W.H. Adey and Lithophyllum pustulatum (J.V. Lamouroux) Foslie were also present with lower abundance. A total of 91 macroalgal species were identified as epiphytes of encrusting Corallinales, among them 11 Ochrophyta, 8 Chlorophyta and 72 Rhodophyta (Appendix 1).

PERMANOVA analysis detected a significant interaction between Condition and Depth; the pairwise 


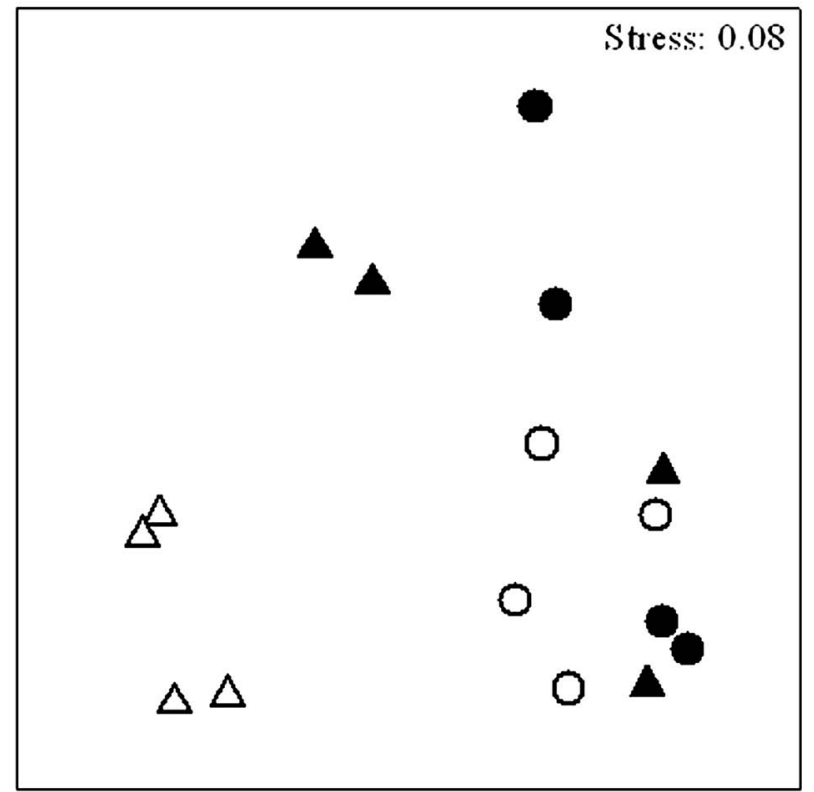

FIG. 3. - Non-metric multidimensional scaling ordination based on Bray-Curtis similarity. White, small islands; black, continental coasts; triangles, $-30 \mathrm{~m}$; circles, $-40 \mathrm{~m}$.

tests showed that the structure of assemblages of the two studied depths differed off islands but not along continental coasts and differences between conditions were significant only at $30 \mathrm{~m}$ depth (Table 1 ). The nMDS showed shallow assemblages off islands and continental coasts to be clearly segregated, while deep assemblages of both types of shore were close to each other. Moreover, deep and shallow assemblages were more separated off islands than off continental coasts (Fig. 3).

Off islands, the main species characterizing shallow coralligenous assemblages were represented by the Chlorophyta Flabellia petiolata, Halimeda tuna and Valonia macrophysa, the Rhodophyta Womersleyella setacea and the Ochrophyta Dictyota linearis, while Meredithia microphylla, Osmundea pelagosae, Zanardina typus, Eupogodon planus and Peyssonnelia spp. were abundant in deeper assemblages (Table 2).
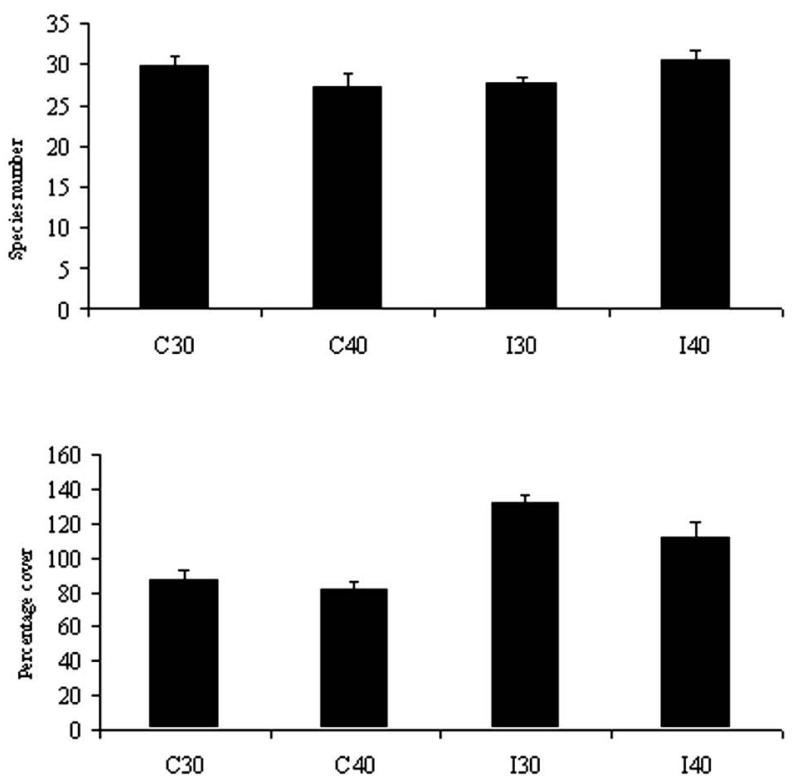

FIG. 4. - Species number per sample and total percentage cover of marcoalgal coralligenous assemblages (encrusting Corallinales excluded). C, continental coast; I, small islands; numbers indicate sampling depths.

At $30 \mathrm{~m}$ depth, off the continental coasts the percent cover of erect Udoteaceae (Flabellia petiolata and Halimeda tuna), Womersleyella setacea, Osmundea pelagosae, Valonia macrophysa and Dictyota linearis was lower than off the islands, while Peyssonnelia rubra, Zanardina typus, Tricleocarpa fragilis, Acrodiscus vidovichii and Meredithia microphylla were more abundant.

ANOVA detected significant interactions between Condition and Depth for both total percentage cover and species number (Table 3). The total percentage cover was lower off continental coasts than off islands at both depths, while the species number showed the same pattern in the deeper assemblages but with an opposite pattern for the shallower one. For both analyses, differences between depths were significant only for islands (Fig. 4).

TABLE 3. - Results of ANOVA analyses on species number and total percentage cover. Significant results are in bold.

\begin{tabular}{|c|c|c|c|c|c|c|c|}
\hline Source & df & $\begin{array}{l}\text { Species number } \\
\text { MS }\end{array}$ & $\mathrm{F}$ & $\mathrm{P}$ & $\begin{array}{c}\text { Percentage cover } \\
\text { MS }\end{array}$ & $\mathrm{F}$ & $\mathrm{P}$ \\
\hline Condition (C) & 1 & 1.687 & 0.03 & 0.855 & 16248.4012 & 15.21 & 0.002 \\
\hline Depth (D) & 1 & 7.520 & 0.15 & 0.701 & 1984.9071 & 1.86 & 0.197 \\
\hline $\mathrm{C} \times \mathrm{D}$ & 12 & 48.715 & 4.48 & 0.001 & 1068.2102 & 6.44 & 0.000 \\
\hline Site $(C \times D)$ & 1 & 136.687 & 2.81 & 0.119 & 576.3864 & 0.54 & 0.476 \\
\hline Residual & 32 & 10.87 & & & 165.8652 & & \\
\hline \multirow[t]{2}{*}{ Total } & 47 & & & & & & \\
\hline & & $\mathrm{C}=0.323(\mathrm{~ns})$ & & & $\mathrm{C}=0.158(\mathrm{~ns})$ & & \\
\hline \multirow[t]{4}{*}{ SNK test $\mathrm{C} \times \mathrm{D}$} & & $-30 \mathrm{~m}$ & Coast & $>$ Island & $-30 \mathrm{~m}$ & Coast & $<$ Island \\
\hline & & $-40 m$ & Coast & $<$ Island & $-40 m$ & Coast & $<$ Island \\
\hline & & Coast & $-30 m$ & $=-40 \mathrm{~m}$ & Coast & $-30 \mathrm{~m}$ & $=-40 \mathrm{~m}$ \\
\hline & & Island & $-30 \mathrm{~m}$ & $<-40 m$ & Island & $-30 \mathrm{~m}$ & $>-40 \mathrm{~m}$ \\
\hline
\end{tabular}




\section{DISCUSSION}

The present study shows that macroalgal coralligenous assemblages differ between depths but this pattern is not consistent along the continental coasts. Consequently, differences between assemblages related to different environmental conditions were more evident in the shallower zone of distribution of coralligenous habitats.

Off the islands, the differences between assemblages colonizing the two studied depths were mostly related to a higher percentage cover of erect Udoteaceae (Flabellia petiolata and Halimeda tuna) in the shallower assemblages and a higher percentage cover of sciaphilous species in the deeper assemblages. A high abundance of Udoteaceae in the shallower zone of coralligenous habitats has been already described in other Mediterranean areas (Ballesteros, 1992; 2006) and it may be considered characteristic of this bathymetric range. On the other hand, the species characterizing the deeper assemblages (Meredithia mycrophylla, Zanardina typus, Eupogodon planus and Peyssonnelia spp.) are typical of coralligenous habitats (Piazzi et al., 2010). Off the continental coasts, the lack of significant differences between the two depths examined were mostly related to the fact that assemblages of both depths were characterized by low cover of erect Udoteaceae and other moderate sciaphilous species, such as Valonia macrophysa and Dictyota linearis, besides a high abundance of typical coralligenous species. This pattern could be related to a reduction of light penetration due to an increase in sedimentation and in other human-induced pollutants (Petrilli et al., 1979; Airoldi et al., 1996; Balata et al., 2005). In fact, previous experimental investigations showed that erect Udoteaceae were sensitive to disturbances such as sedimentation and colonization of the invasive species Caulerpa racemosa (Forsskål) C. Agardh var. cylindracea (Sonder) Verlaque, Huisman et Boudouresque (Balata et al., 2007a, 2007b; Piazzi and Balata, 2008).

In the shallower assemblages the total percentage cover was lower along continental coasts than around islands due to the decrease in erect Udoteaceae; an opposite pattern was observed for the species number per plot. Around islands, richness increased in deeper assemblages following a common pattern for rocky subtidal systems (Garrabou et al., 2002). Along the continental coasts, the lack of Udoteaceae probably favoured the spread of less competitive species, leading to an increase in richness in shallower assemblages and altering patterns of vertical distribution.

Species richness is similar along the coasts and islands ( 80 vs 83 species), but the decrease of differences among assemblages related to different depths along the coasts may lead to a higher spatial homogenization and an impoverishment of the system (Olden et al., 2004). In fact, beta diversity, defined as the change of species composition and abundance along environmental gradients (between-habitat diversity), is an important aspect for ecological studies and contributes highly to the total diversity of marine systems (Legendre et al., 2005; Gray, 1997, 2000). It is known that changes in alphadiversity can be completely uncoupled from betweenhabitat homogenization (Olden and Poff, 2003); thus, the replacement of locally distinctive assemblages with widespread species caused by disturbance could lead to a decrease in beta-diversity while alpha-diversity could remain unchanged (Smart at al., 2006).

This correlative study does not reveal any causeeffect relationships; however, patterns detected in the present study are in agreement with the results of manipulative studies (Balata et al., 2007a, 2007b), suggesting that different environmental conditions, mostly related to different levels of sedimentation and pollution, can be the cause of the observed patterns. Further studies considering different kinds of disturbance are necessary in order to test the model that environmental conditions can modify vertical patterns of distribution of coralligenous assemblages. Moreover, sessile animals, which in the present study were not considered, are determinant for the structure and functioning of these systems (Cocito et al., 2002; Cocito, 2004) and they may be an interesting topic for further research.

\section{REFERENCES}

Airoldi, L. - 2003. The effects of sedimentation on rocky coastal assemblages. Oceanogr. Mar. Biol. Annu. Rev., 41: 161-203.

Airoldi, L., M. Fabiano and F. Cinelli. - 1996. Sediment deposition and movement over a turf assemblage in a shallow rocky coastal area of the Ligurian Sea. Mar. Ecol. Progr. Ser., 133: 241-251.

Anderson, M.J. - 2001. A new method for a non-parametric multivariate analysis of variance. Austr. Ecol., 26: 32-46.

Balata, D. and L. Piazzi. - 2008. Patterns of diversity in rocky subtidal macroalgal assemblages in relation to depth. Bot. Mar., 51: 464-471.

Balata D., L. Piazzi, E. Cecchi and F. Cinelli. - 2005. Variability of Mediterranean coralligenous assemblages subject to local variation in sediment deposits. Mar. Environ. Res., 60: 403-421.

Balata D., S. Acunto and F. Cinelli. - 2006. Spatio-temporal variability and vertical distribution of a low rocky subtidal assemblage in the north-west Mediterranean. Estuar. Coast. Shelf Sci., 67: 553-561.

Balata D., L. Piazzi and L. Benedetti-Cecchi. - 2007a. Sediment disturbance and loss of beta diversity on subtidal rocky reefs. Ecology, 88: 2455-2461.

Balata D., L. Piazzi and F. Cinelli. - 2007b. Increase of sedimentation in a subtidal system: effects on the structure and diversity of macroalgal assemblages. J. Exp. Mar. Biol. Ecol., 351: 73-82.

Ballesteros, E. - 1992. Els vegetals i la zonació litoral: espècies, comunitats i factors que influeixen en la seva distribució. Arx. Sec. Cièn. Inst. Est. Catalans, 101: 1-616.

Ballesteros, E. - 2006. Mediterranean coralligenous assemblages: a synthesis of present knowledge. Oceanogr. Mar. Biol. Annu. Rev., 44: 123-195.

Benedetti-Cecchi L., F. Bulleri and F. Cinelli. - 2000. The interplay of physical and biological factors in maintaining mid-shore and low-shore assemblages on rocky coasts in the northwest Mediterranean. Oecologia, 123: 406-417.

Benedetti-Cecchi, L., E. Maggi, I. Bertocci, S. Vaselli, F. Micheli, G.C. Osio and F. Cinelli. - 2003. Variation in rocky shore assemblages in the northwestern Mediterranean: contrasts between islands and the mainland. J. Exp. Mar. Biol. Ecol., 293: 193-215.

Boudouresque, C.F. - 1971. Méthodes d'étude qualitative et quantitative du benthos (en particulier du phytobenthos). Tethys, 3 : 79-104.

Boudouresque, C.F. - 1973. Recherche de bionomie analytique 
structurale et expérimentale sur les peuplements sciaphiles de Méditerranée occidentale (fraction algale). Les peuplements sciaphiles de mode relativement calme sur substrats durs. Bull. Mus. Hist. Nat., 33: 147-225.

Chapman, M.G., A.J. Underwood and G.A. Skilleter. - 1995. Variability at different spatial scales between a subtidal assemblage exposed to discharge of sewage and two control assemblages. $J$. Exp. Mar. Biol. Ecol., 189: 103-122.

Clarke, K.R. - 1993. Non-parametric multivariate analyses of changes in community structure. Austr. Ecol., 18: 117-143.

Cocito, S. - 2004. Bioconstruction and biodiversity: their mutual influence. Sci. Mar., 68(Suppl. 1): 137-144.

Cocito S., D. Bedulli and S. Sgorbini. - 2002. Distribution patterns of the sublittoral epibenthic assemblages on a rocky shoal in the Ligurian Sea (NW Mediterranean). Sci. Mar., 66(2): 175-181.

Dauer, D.M., R.J. Llanso and M.F. Lane. - 2008. Depth-related patterns in benthic community condition along an estuarine gradient in Chesapeake Bay. Ecol. Ind., 8: 417-424.

Diez, I., A. Santolaria and J.M. Gorostiaga. - 2003. The relationship of environmental factors to the structure and distribution of subtidal seaweed vegetation of the western Basque coast ( $\mathrm{N}$ Spain). Estuar. Coast. Shelf Sci., 56: 1041-1054.

Garrabou, J., E. Ballesteros and M. Zabala. - 2002. Structure and dynamics of north-western Mediterranean rocky benthic communities along a depth gradient. Estuar. Coast. Shelf Sci., 55: 493-508.

Gili, J.M. and J.D. Ros. - 1985. Study and cartography of benthic communities of Medes Islands (NE Spain). PSZNI: Mar. Ecol., 6: 219-238.

Glasby, T.M. and S.D. Connell. - 2001. Orientation and position of substrata have large effects on epibiotic assemblages. Mar. Ecol. Progr. Ser., 214: 127-135.

Gray, J.S. - 1997. Marine biodiversity: patterns, threats and conservation needs. Biodiv. Conserv., 6: 153-175.

Gray, J.S. - 2000. The measurement of marine species diversity, with an application to the benthic fauna of the Norwegian continental shelf. J. Exp. Mar. Biol. Ecol., 250: 23-49.

Guiry, M.D. and E. Nic Dhonncha. - 2009. Algae Base. World Wide Web electronic publication www.algaebase.org.

Irving, A.D. and S.D. Connell. - 2002. Sedimentation and light penetration interact to maintain heterogeneity of subtidal habitats: algal versus invertebrate dominated assemblages. Mar. Ecol. Progr. Ser., 245: 83-91.

Konar, B., K. Ilken and M. Edwards. - 2009. Depth-stratified community zonation patterns on Gulf of Alaska rocky shores. Mar. Ecol., 30: 63-73.

Legendre, P., D. Borcard and P.R. Peres-Neto. - 2005. Analyzing beta diversity: partitioning the spatial variation of community composition data. Ecol. Monogr., 75: 435-450.

Olden, J.D. and N.L. Poff. - 2003. Ecological mechanisms driving biotic homogenization: testing a mechanistic model using fish fauna. Ecology, 85: 1867-1875.

Olden, J.D., N.L. Poff, M.R. Douglas, M.E. Douglas and K.D. Fausch. - 2004. Ecological and evolutionary consequences of biotic homogenization. Trends Ecol. Evol., 19: 18-24.

Pérès, J.M. and J. Picard. - 1964. Nouveau manuel de bionomie benthique de la Méditerranée. Rec. Trav. Stat. Mar. Endoume, 3: 1-137.

Petrilli, F.L., G. De Renzi, P. Palmerini, R. Morelli and S. De Flora. - 1979. Survey of the pollution in a coastal area of the Thyrrenian Sea. Aerial photography, physic-chemical and microbiological investigations and mutagenic monitoring. Water Res., 13: 895-904.

Piazzi, L. and D. Balata. - 2008. The spread of Caulerpa racemosa var. cylindracea in the Mediterranean Sea: an example of how biological invasions can influence beta diversity. Mar. Env. Res., 65: 50-61.

Piazzi, L., D. Balata and F. Cinelli. - 2007. Invasions of alien macroalgae in Mediterranean coralligenous assemblages. Cryptogamie Algol., 28: 289-301.

Piazzi, L., D. Balata, E. Cecchi, F. Cinelli and G. Sartoni. - 2010. Species composition and patterns of diversity of macroalgal coralligenous assemblages in the north-western Mediterranean Sea. J. Nat. Hist., 44: 1-22.

Smart, S.M., K. Thompson, R.H. Marris, M.G. Le Duc, L.C. Maskell and L.G. Firbank. - 2006. Biotic homogenization and changes in species diversity across human-modified ecosystems. Proc. R. Soc. B., 273: 2659-2665

Terlizzi, A., M. J. Anderson, S. Fraschetti and L. Benedetti-Cecchi. - 2010. Scales of spatial variation in Mediterranean subtidal sessile assemblages at different depths. Mar. Ecol. Progr. Ser., (in press).

Underwood, A.J. - 1992. Competition and plant-animal interaction. In: D.M. John, S.J. Hawkins and J.H. Price (eds.), Plant-Animal interaction in the marine benthos. Syst. Assoc. Spec. Vol., 46: 443-475.

Underwood, A.J. - 1997. Experiments in ecology. Their logical design and interpretation using analysis of variance. Cambridge Univ. Press, Cambridge.

Vadas, R.L. and R.S. Steneck. - 1988. Zonation of deep water benthic algae in the Gulf of Maine. J. Phycol., 24: 338-346.

Scient. ed.: E. Ballesteros.

Received April 26, 2010. Accepted November 15, 2010.

Published online March 14, 2011. 
APPEndix 1. - Floristic list

\begin{tabular}{lllll}
\hline TAXA & Coast & & Island & \\
\hline FUCOPHYCEAE & $-30 \mathrm{~m}$ & $-40 \mathrm{~m}$ & $-30 \mathrm{~m}$ & $-40 \mathrm{~m}$ \\
\hline
\end{tabular}

FUCOPHYCEAE

Asperococcus bullosus J.V. Lamouroux

Cladosiphon irregularis (Sauvageau) Kylin

Cutleria chilosa (Falkenberg) P.C. Silva (sporophyte "Aglaozonia")

Dictyota linearis (C. Agardh) Greville

Halopteris filicina (Grateloup) Kützing

Nereia filiformis (J. Agardh) Zanardini

Spermatochnus paradoxus (P.H. Roth) Kützing

Sphacelaria cirrosa (P.H. Roth) C. Agardh

Sphacelaria plumula Zanardini

Stictyosiphon adriaticus Kützing

Zanardinia typus (Nardo) P.C. Silva

Chlorophyta

Cladophora echinus (Biasoletto) Kützing

Cladophora prolifera (Roth) Kützing

Flabellia petiolata (Turra) Nizamuddin

Halimeda tuna (J. Ellis et Solander) J.V. Lamouroux

Microdictyon tenuius Decaisne ex J.E. Gray

Palmophyllum crassum (Naccari) Rabenhorst

Pseudochlorodesmis furcellata (Zanardini) Børgesen

Valonia macrophysa Kützing

RHODOPHYTA

Acrodiscus vidovichii (Meneghini) Zanardini

Acrosorium ciliolatum (Harvey) Kylin

Acrothamnion preissii (Sonder) Wollaston

Aglaothamnion tenuissimum (Bonnemaison) Feldmann-Mazoyer

Aglaothamnion tripinnatum (C. Agardh) Feldmann-Mazoyer

Amphiroa rubra (Philippi) Woelkerling

Antithamnion cruciatum (C. Agardh) Nägeli

Antithamnion heterocladum Funk

Anthithamnion piliferum Cormaci et $\mathrm{G}$. Furnari

Antithamnion tenuissimum (Hauck) Schiffner

Apoglossum gregarium (Dawson) M.J. Winne

Apoglossum ruscifolium (Turner) J. Agardh

Botryocladia botryoides (Wulfen) Feldmann

Brongniartella byssoides (Goodenough et Woodward) F. Schmitz

Ceramium bertholdii Funk

Ceramium bisporum Ballantine

Ceramium cimbricum H.E. Petersen

Ceramium codii (H. Richards) Feldmann-Mazoyer

Ceramium diaphanum (Lightfoot) P.H. Roth

Ceramium flaccidum (Kützing) Ardissone

Ceramium tenerrimum (G. Martens) Okamura

Champia parvula (C. Agardh) Harvey

Chondria capillaris (Hudson) M.J. Wynne

Chrysymenia ventricosa (J.V. Lamouroux) J. Agardh

Contarinia peyssonneliaeformis Zanardini

Contarinia squamariae (Meneghini) Denizot

Dasya corymbifera J. Agardh

Dasya ocellata (Grateloup) Harvey

Dasya rigidula (Kützing) Ardissone

Erythroglossum sandrianum (Kützing) Kylin

Eupogodon planus (C. Agardh) Kützing

"Falkenbergia rufolanosa (Harvey) F. Schmitz «stadium sporophyte of Asparagopsis armata Harvey

Feldmannophycus rayssiae (Feldmann et Feldmann-Mazoyer) Augier et Boudouresque

Gelidium bipectinatum $\mathrm{G}$. Furnari

Griffithsia schousboei Montagne

Halydyction mirabile Zanardini

Herposiphonia secunda (C. Agardh) Ambronn

Heterosiphonia crispella (C. Agardh) M.J. Wynne

Hypoglossum hypoglossoides (Stackhouse) Collins et Harvey

Irvinea boergesenii (Feldmann) R.J. Wilkes, L.M. McIvor et Guiry

Jania adhaerens J.V. Lamouroux

Laurencia chondrioides Børgesen

Lomentaria chylocladiella Funk

Lomentaria ercegovicii Verlaque, Boudouresque, Meinesz, Giraud et Marcot Coqueugniot

Meredithia microphylla (J. Agardh) J. Agardh

Monosporus pedicellatus (J.E. Smith) Solier

\begin{tabular}{|c|c|c|c|}
\hline+ & + & + & + \\
\hline- & - & + & - \\
\hline- & - & + & - \\
\hline+ & - & + & - \\
\hline+ & + & + & + \\
\hline+ & - & - & + \\
\hline- & - & - & + \\
\hline+ & + & + & + \\
\hline+ & + & + & + \\
\hline- & - & - & + \\
\hline+ & + & + & + \\
\hline+ & + & + & + \\
\hline+ & + & + & + \\
\hline+ & + & + & + \\
\hline+ & - & + & + \\
\hline- & - & + & + \\
\hline- & + & + & + \\
\hline+ & + & + & + \\
\hline+ & + & + & + \\
\hline+ & + & + & + \\
\hline+ & + & + & - \\
\hline+ & + & + & + \\
\hline+ & + & + & + \\
\hline+ & - & - & - \\
\hline+ & - & + & - \\
\hline+ & + & + & + \\
\hline+ & + & - & - \\
\hline+ & - & + & - \\
\hline+ & + & + & + \\
\hline+ & + & + & + \\
\hline+ & + & + & + \\
\hline+ & + & + & + \\
\hline- & - & - & + \\
\hline+ & - & + & + \\
\hline+ & + & + & + \\
\hline- & - & + & + \\
\hline+ & + & + & + \\
\hline+ & - & + & - \\
\hline+ & + & + & + \\
\hline- & - & + & - \\
\hline+ & + & + & + \\
\hline- & + & + & + \\
\hline- & + & - & - \\
\hline+ & - & - & - \\
\hline+ & + & + & + \\
\hline- & - & - & + \\
\hline+ & + & + & + \\
\hline+ & - & + & + \\
\hline+ & + & - & + \\
\hline+ & + & + & + \\
\hline+ & - & + & + \\
\hline+ & + & + & + \\
\hline+ & + & + & + \\
\hline+ & + & + & - \\
\hline+ & - & + & + \\
\hline- & - & + & - \\
\hline+ & + & + & + \\
\hline+ & + & + & + \\
\hline- & + & - & - \\
\hline+ & - & + & - \\
\hline+ & + & + & + \\
\hline+ & + & + & - \\
\hline- & - & + & - \\
\hline+ & + & + & + \\
\hline+ & + & + & + \\
\hline
\end{tabular}


406 $\bullet$ L. PIAZZI and D. BALATA

APPENDIX 1 (cont.). - Floristic list

\begin{tabular}{|c|c|c|c|c|}
\hline \multirow[b]{2}{*}{ TAXA } & \multicolumn{2}{|c|}{ Coast } & \multicolumn{2}{|c|}{ Island } \\
\hline & $-30 \mathrm{~m}$ & $-40 \mathrm{~m}$ & $-30 \mathrm{~m}$ & $-40 m$ \\
\hline Neurocaulon foliosum (Meneghini) Zanardini & + & + & - & + \\
\hline Osmundea pelagosae (Schiffner) F.W. Nam & + & + & + & + \\
\hline Peyssonnelia rubra (Greville) J. Agardh & + & + & + & + \\
\hline Peyssonnelia squamaria (S.G. Gmelin) Decaisne & + & - & + & + \\
\hline Peyssonnelia stoechas Boudouresque et Denizot & + & + & - & - \\
\hline Phyllophora crispa (Hudson) P.S. Dixon & - & + & - & + \\
\hline Plocamium cartilagineum (Linnaeus) P.S. Dixon & + & + & + & + \\
\hline Polysiphonia elongata (Hudson) Sprengel & + & - & + & + \\
\hline Polysiphonia furcellata (C. Agardh) Harvey & + & + & + & + \\
\hline Polysiphonia perforans Cormaci, G. Furnari, Pizzuto et Serio & + & + & + & + \\
\hline Polysiphonia subulifera (C. Agardh) Harvey & + & + & + & + \\
\hline Pterothamnion plumula (J. Ellis) Nägeli & + & + & - & - \\
\hline Ptilothamnion pluma (Dillwyn) Thuret & + & + & + & + \\
\hline Radicilingua reptans (Kylin) Papenfuss & + & - & + & + \\
\hline Rhodophyllis divaricata (Stackhouse) Papenfuss & + & + & + & + \\
\hline Rhodymenia ardissonei J. Feldmann & + & + & + & + \\
\hline Rodriguezella pinnata Ercegovic & + & + & + & + \\
\hline Rodriguezella strafforelloi $\mathrm{F}$. Schmitz & + & + & - & + \\
\hline Rytiphlaea tinctoria (Clemente) C. Agardh & + & + & - & + \\
\hline Schmitzia neapolitana (Berthold) P.C. Silva & + & + & + & + \\
\hline Spermothamnion repens (Dillwyn) Rosenvinge & + & - & - & + \\
\hline Sphaerococcus coronopifolius Stackhouse & + & + & - & - \\
\hline Spyridia filamentosa (Wulfen) Harvey & - & - & - & + \\
\hline Tricleocarpa fragilis (Linnaeus) Huisman et R.A. Towsend & + & + & - & - \\
\hline Womersleyella setacea (Hollenberg) R.E. Norris & + & + & + & + \\
\hline Wrangelia penicillata (C. Agardh) C. Agardh & + & - & + & - \\
\hline
\end{tabular}

